\title{
Bicyclic Lactams derived from Serine or Cysteine and 2-Methylpropanal
}

Halima Bagum, ${ }^{\dagger}$ Bethany R. Shire, ${ }^{\dagger}$ Kirsten E. Christensen, ${ }^{\dagger}$ Miroslav Genov,${ }^{\dagger}$ Alexander Pretsch, ${ }^{\dagger}$ Dagmar Pretsch, ${ }^{+}$and Mark G. Moloney*,†,\#

†The Department of Chemistry, Chemistry Research Laboratory, University of Oxford, 12 Mansfield Road, Oxford. OX1 3TA

\#Oxford Suzhou Centre for Advanced Research, Building A, 388 Ruo Shui Road, Suzhou Industrial Park, Jiangsu, 215123, P.R. China.

†Oxford Antibiotic Group, The Oxford Science Park, Magdalen Centre, Oxford OX4 4GA, UK.

mark.moloney@chem.ox.ac.uk

\begin{abstract}
Bicyclic lactams may be prepared from serine or cysteine and 2-methylpropanal; the resulting $S, N$ - heterocycles are more stable than the $O, N$ - heterocycles but both are synthetic intermediates capable of further elaboration.
\end{abstract}

We have shown that L-serine, L-cysteine, L-allothreonine and L-threonine methyl esters 1a-d may be converted to their corresponding $O, N$ - or $S, N$-heterocycles $\mathbf{2 a - d}$ by reaction with pivaldehyde, and that these in turn may be converted to tetramates 3a-d by a highly chemo- and enantioselective Dieckmann cyclisation using the literature protocols. ${ }^{1,2,3}$ The $t$-butyl group acts simultaneously as a protecting and chemoselective directing group, principally from its bulk. One disadvantage of this process is the expense and availability of pivaldehyde, and the question arose whether 2methylpropanal might provide an alternative. Although the use of other aldehydes and especially benzaldehydes has been shown for cysteine, ${ }^{4}$ where the $S, N$-heterocycles are more stable, ${ }^{5,}{ }^{6}$ the possibility of similar variation for the $O, N$-heterocycle system was less certain. The feasibility of preparing and using such tetramates have been investigated and is reported here. 


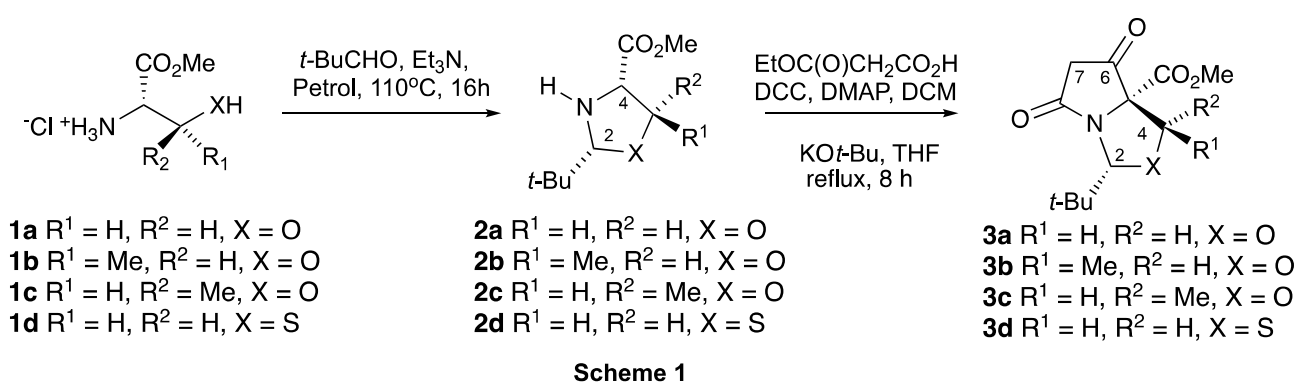

Methyl ester hydrochlorides of the amino acids L-serine and L-cysteine 1a and 1d were treated with 2-methylpropanal/triethylamine following Seebach's protocol (Scheme 1) ${ }^{7}$ to furnish oxazolidine $\mathbf{4 a}$ and thiazolidine $\mathbf{4 b}$ as mixtures of diastereomers which were used directly without purification; the preference of the latter for cis-2,5 diastereomer results from ring-chain tautomerism giving the more stable isomer. $5,8,9$ DCC coupling gave malonamides $\mathbf{5 a , b}$ and subsequent Dieckmann cyclization afforded the novel methyl ester tetramates 6a (14\%) or $\mathbf{6 b}$ $(47 \%) ;{ }^{10}$ the relative stereochemistry of key intermediates was established NOE analysis (Figure 1). It is evident that the isopropyl group is capable of directing a similar chemical outcome to that of the $t$-butyl group, ${ }^{8,11}$ although this comes with complication in the NMR spectrum as a result of the non-symmetrical nature of the isopropyl system. In the case of the thiazolidine system, bicyclic tetramate $\mathbf{6 b}$ was obtained along with decarboxylated $\mathbf{6 c}$ as an inseparable mixture. Tetramates 6a,b were readily converted to mesylates $7 \mathbf{a}, \mathbf{b}$ in 14 and $64 \%$ yield; ${ }^{10}$ the significantly better yields in the case of the latter again reflect the better stability to acid (and therefore chromatography) of the $S, N$ - system over the $O, N$ - one. For the oxazolidine system, difficulties with purification, thought to arise from the greater acid sensitivity of this system, meant that crude material needed to be taken on until formation of the mesylate $\mathbf{7 a}$, which could readily be isolated in pure form. With mesylates 7a,b in hand, Suzuki coupling with 1.5 eq of aryl boronic acid resulted pyrrolinone derivatives 8ai-iii and 8bi-iii (Table 1). ${ }^{10}$ The structures of 8 aii and $\mathbf{8 b i i}$ were further confirmed by single crystal x-ray analysis (Figure 2). ${ }^{12}$ 


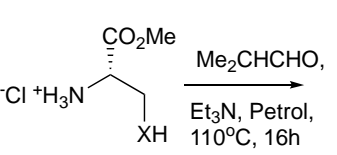

$$
\begin{aligned}
& 1 a X=O \\
& 1 b X=S
\end{aligned}
$$

$4 b X=S(76 \%)$

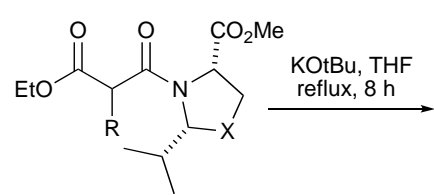

5a $\mathrm{R}=\mathrm{H}, \mathrm{X}=\mathrm{O}$

5b $\mathrm{R}=\mathrm{H}, \mathrm{X}=\mathrm{S}(74 \%)$

5c $R=M e, X=S(81 \%)$

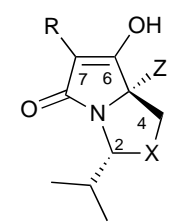

6a $\mathrm{R}=\mathrm{H}, \mathrm{X}=\mathrm{O}, \mathrm{Z}=\mathrm{CO}_{2} \mathrm{Me}$

6b $\mathrm{R}=\mathrm{H}, \mathrm{X}=\mathrm{S}, \mathrm{Z}=\mathrm{CO}_{2} \mathrm{Me}(47 \%)$

6c $\mathrm{R}=\mathrm{H}, \mathrm{X}=\mathrm{S}, \mathrm{Z}=\mathrm{H}$

6d $\mathrm{R}=\mathrm{Me}, \mathrm{X}=\mathrm{S}, \mathrm{Z}=\mathrm{CO}_{2} \mathrm{Me}(76 \%)$

6e $R=M e, X=S, Z=H(13 \%)$
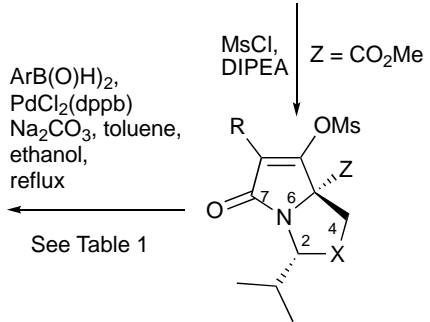

7a $\mathrm{R}=\mathrm{H}, \mathrm{X}=\mathrm{O}, \mathrm{Z}=\mathrm{CO}_{2} \mathrm{Me}(14 \%)$ 7b $\mathrm{R}=\mathrm{H}, \mathrm{X}=\mathrm{S}, \mathrm{Z}=\mathrm{CO}_{2} \mathrm{Me}(64 \%)$

7c $\mathrm{R}=\mathrm{H}, \mathrm{X}=\mathrm{S}, \mathrm{Z}=\mathrm{H}$

7d $\mathrm{R}=\mathrm{Me}, \mathrm{X}=\mathrm{S}, \mathrm{Z}=\mathrm{CO}_{2} \mathrm{Me}(61 \%)$

7e $R=M e, X=S, Z=H(13 \%)$

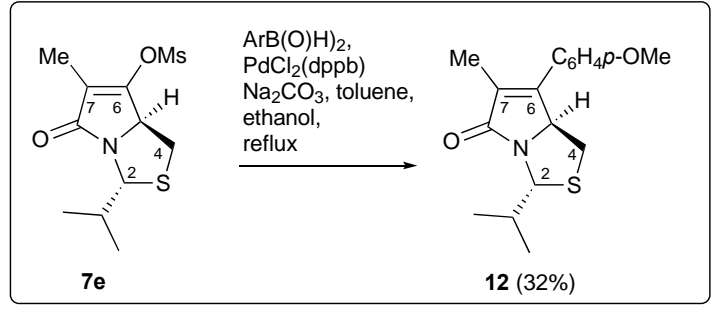

TFA,

8a $\mathrm{R}=\mathrm{H}, \mathrm{X}=\mathrm{O}$

8c $R=M e, X=S$

\begin{tabular}{l|l} 
TFA, \\
$\mathrm{HSCH} \mathrm{CH}_{2} \mathrm{CH}_{2} \mathrm{SH}$, & $\mathrm{Ar}=\mathrm{Ph}$ \\
$\mathrm{CF}_{3} \mathrm{CH}_{2} \mathrm{OH}$ &
\end{tabular}

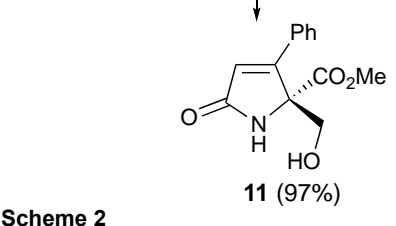

Scheme 2

$11(97 \%)$

Table 1: Suzuki coupling of 7a,b with arylboronic acids and hydrogenation of 8ai-aiii.

\begin{tabular}{|c|c|c|c|c|c|c|c|}
\hline Compound & $\mathbf{A r}$ & $\begin{array}{c}\text { Reaction } \\
\text { time (h) }\end{array}$ & Product & $\begin{array}{c}\text { Yield } \\
(\%)\end{array}$ & $\begin{array}{c}\text { Reaction } \\
\text { time (h) }\end{array}$ & Product & $\begin{array}{c}\text { Yield } \\
(\%)\end{array}$ \\
\hline $\mathbf{7 a}$ & $4-\mathrm{MeOC}_{6} \mathrm{H}_{4}$ & 6 & $\mathbf{8 a i}$ & 47 & 6 & 9ai & 82 \\
\hline & $\mathrm{C}_{6} \mathrm{H} 5$ & 6 & $\mathbf{8 a i i}$ & 45 & 5 & 9aii & 75 \\
\hline & $4-\mathrm{ClC}_{6} \mathrm{H}_{4}$ & 3 & $\mathbf{8 a i i i}$ & 40 & 6 & 9aiii & 85 \\
\hline $\mathbf{7 b}$ & $4-\mathrm{MeOC}_{6} \mathrm{H}_{4}$ & 3 & $\mathbf{8 b i}$ & 72 & - & - & - \\
\hline & $\mathrm{C}_{6} \mathrm{H}_{5}$ & 3 & $\mathbf{8 b i i}$ & 74 & - & - & - \\
\hline $\mathbf{7 c}$ & $4-\mathrm{ClC}_{6} \mathrm{H}_{4}$ & 5 & $\mathbf{8 b i i i}$ & 41 & - & - & - \\
\hline & $4-\mathrm{MeOC}_{6} \mathrm{H}_{4}$ & $24 \mathrm{~h}$ & $\mathbf{8 c i}$ & 13 & - & - & - \\
\hline & $\mathrm{C}_{6} \mathrm{H}_{5}$ & $20 \mathrm{~h}$ & $\mathbf{8 c i i}$ & 12 & - & - & - \\
\hline & $4-\mathrm{ClC}_{6} \mathrm{H}_{4}$ & $24 \mathrm{~h}$ & $\mathbf{8 c i i i}$ & 11 & - & - & - \\
\hline
\end{tabular}

a 4-chlorophenylboronic acid: 1.05 eq 


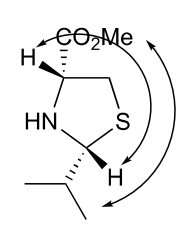

$4 b$

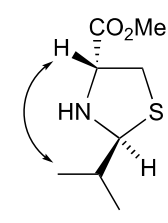

4b

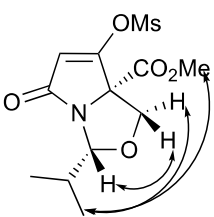

$7 a$

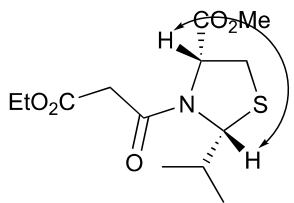

$5 b$

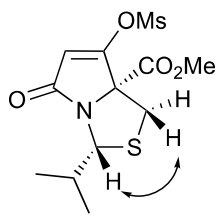

7b

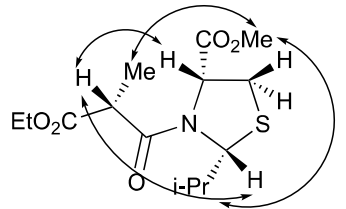

$5 c$

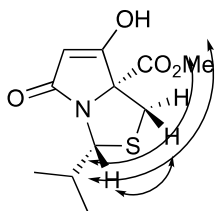

6b

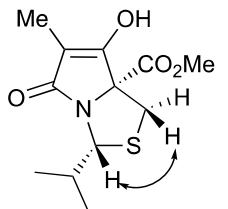

6d

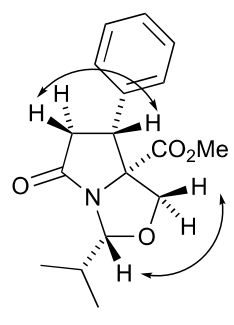

9aii

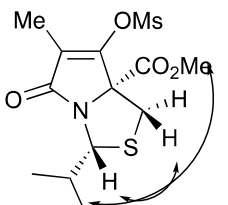

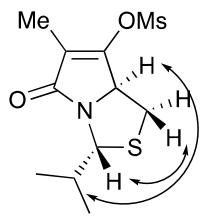

$7 e$

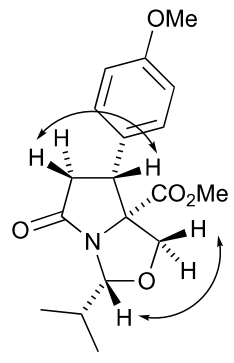

9ai

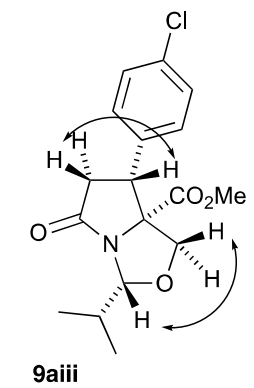

Figure 1

Figure 1: NOE Analysis of selected compounds.

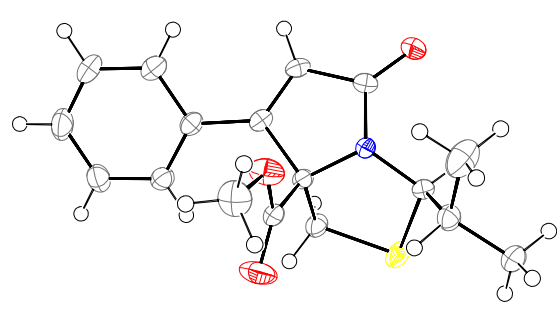

8ail

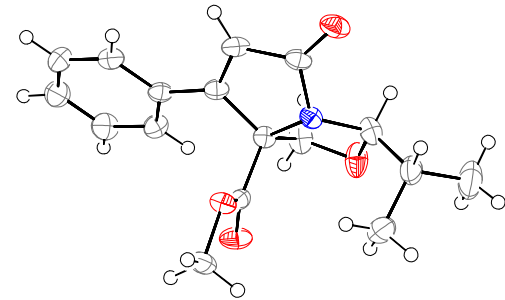

8 bii

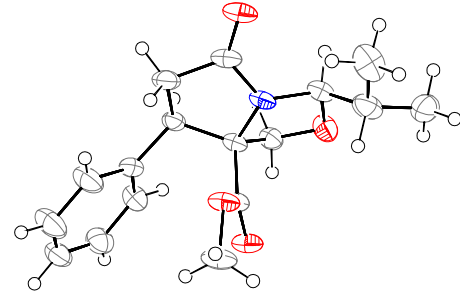

9ii

Figure 2: Single crystal X-Ray crystal structure of 8aii, 8bii, 9aii. ${ }^{12}$ Displacement ellipsoids are drawn at $50 \%$ probability.

Treatment of pyrrolinones 8ai-iii with $\mathrm{H}_{2} / \mathrm{PtO}_{2}$ furnished acid derivatives 9ai-iii in high yields (Table 1), and of interest was that the isolation of these products by flash column chromatography was straightforward. Their stereochemistry was assigned by NOE analysis, all of showing strong NOE between endo-H4-H2 and endo-H7-H6 (Figure 1) and further confirmed by the X-ray crystal structure of 9aii (Figure 2). ${ }^{12}$ Representative compounds 8aii and 9ai were subjected to $N, O$-acetal deprotection using Corey-Reichard protocol ${ }^{13}$ and gave the pyroglutaminols $\mathbf{1 0}$ and $\mathbf{1 1}$ in excellent 
yield (Scheme 2). The easier deprotection of the isopropyl system over the $t$-butyl one is noteworthy, and again reflects their increased acid lability. ${ }^{1}$

This approach could also be extended by $N$-acylation of thiazolidine $\mathbf{4 b}$ with ethyl $\alpha$ methylmalonyl chloride and pyridine to furnish cis-2,5 malonamide 5c (Scheme), found as a mixture of $\mathrm{C} 7$ epimers with $7 R$ as a major one (NOE, Figure 1) and $1 \mathrm{D}$ gradient NMR spectroscopy showed the presence of rotameric exchange. Dieckmann cyclisation under basic conditions resulted in inseparable C7-methyl tetramates $\mathbf{6 d}$ and $\mathbf{6 e} .{ }^{10}$ The stereochemistry of the major tetramic acid $\mathbf{6 d}$ was determined by NOE analysis (Figure 1). The treatment of this mixture with MsCl/DIPEA gave mesylates $7 \mathbf{d}$ and $7 \mathbf{e}$ in $61 \%$ and $13 \%$ isolated yield, respectively. ${ }^{10}$ The stereochemistry of both mesylates 7d and 7e were confirmed by NOE analysis (Figure 1), and Suzuki coupling with arylboronic acids furnished the desired coupling adducts 8ci-iii and $\mathbf{1 2}$ (Scheme 1 and Table 2). ${ }^{10}$ However, the reaction was much slower in this case and probably reflects the greater steric bulk in this system.

Broth assay of some of these compounds (8ai-aiii, 8bi-biii, 8ci-8ciii and 13) against Gram positive (Methicillin resistant Staphylococcus aureus) and Gram negative (Escherichia coli (EC 34) bacteria showed no activity, confirming earlier results seen with related pyroglutamate derivatives. ${ }^{14}$

\section{Conclusion}

We have shown that bicyclic lactams may be prepared from serine or cysteine and 2methylpropanal; the resulting $S, N$ - heterocycles are more stable than the $O, N$ - heterocycles but both are synthetic intermediates capable of further elaboration. This approach neatly complements earlier work leading to C-6 and C-7 functionalisation in related bicyclic systems. ${ }^{15}$

\section{Acknowledgements}

H.B. gratefully acknowledges the award of a Commonwealth Scholarship. 


\section{References}

Dieckmann Cyclisation: ${ }^{3}$ To a solution of $N$-acyl oxazolidine or thiazolidine $\mathbf{5 a , b}(1.0$ eq) in anhydrous THF was added potassium tert-butoxide (1.05 eq). The mixture was heated at reflux for $3 \mathrm{~h}$. The reaction mixture was separated between $\mathrm{Et}_{2} \mathrm{O}$ and water, the aqueous phase was acidified with $2 \mathrm{M}$ aqueous $\mathrm{HCl}$ and extracted with EtOAc. The organic layer was washed with a $1 \mathrm{M}$ aqueous solution of $\mathrm{NaH}_{2} \mathrm{PO}_{4}$ and brine, dried over anhydrous $\mathrm{Na}_{2} \mathrm{SO}_{4}$ and concentrated under reduced pressure to give the methyl ester tetramic acids 6a-e.

Synthesis of Mesylate: ${ }^{16}$ Tetramic acid 6a-e (1.0 eq) was dissolved in DCM under nitrogen atmosphere. Methanesulfonyl chloride (1 eq) and DIPEA (2 eq) were added to this solution. The resulting mixture was stirred for 2-6 h at room temperature until total consumption of the starting material. The reaction mixture was washed with $5 \% \mathrm{HCl}, 5 \% \mathrm{NaHCO}_{3}$, and brine, dried over $\mathrm{MgSO}_{4}$, and filtered. The solvent was removed in vacuo, and the residue was chromatographed on silica gel using ethyl acetate:petroleum ether as eluants to give mesylates 7a,c.

Representative reaction: Tetramic acids $(\mathbf{6 d}+\mathbf{6 e}, 2.32 \mathrm{~g}, 8.55 \mathrm{mmol})$ was reacted with $\mathrm{MsCl}(0.66$ $\mathrm{mL}, 8.55 \mathrm{mmol})$ and DIPEA $(2.9 \mathrm{~mL}, 17.1 \mathrm{mmol})$ in DCM $(85 \mathrm{~mL})$. Purification by flash column chromatography (20-30\% EtOAc in petroleum ether) furnished isolated mesylates 7d and 7e. Yield $61 \%(1.82 \mathrm{~g})$; colourless oil; $\mathrm{R}_{\mathrm{f}}(40 \%$ EtOAc in Petrol $) 0.37 ;[\alpha]_{\mathrm{a}}^{25}+235.0(c 1.0 \mathrm{in} \mathrm{DCM}) ; v_{\max } / \mathrm{cm}^{-}$ ${ }^{1} 2960(\mathrm{C}-\mathrm{H}), 2935(\mathrm{C}-\mathrm{H}), 1747(\mathrm{C}=\mathrm{O}), 1713(\mathrm{C}=\mathrm{O})$; $\delta_{\mathrm{H}}\left(400 \mathrm{MHz}, \mathrm{CDCl}_{3}\right)$ : 0.87 (3H, d, J 6.6, $\left.\mathrm{CH}\left(\mathrm{C}_{3}\right)\right), 1.02\left(3 \mathrm{H}, \mathrm{d}, J\right.$ 6.6, $\left.\mathrm{CH}\left(\mathrm{C}_{3}\right)\right), 1.78-1.84\left(1 \mathrm{H}, \mathrm{m}, \mathrm{C} \underline{\mathrm{H}}\left(\mathrm{CH}_{3}\right)_{2}\right), 1.85\left(3 \mathrm{H}, \mathrm{s}, \mathrm{C}(7) \mathrm{CH}_{3}\right)$, $2.84\left(1 \mathrm{H}, \mathrm{d}, J 11.1, \mathrm{C}(4) \underline{\mathrm{H}}_{\mathrm{A}} \mathrm{H}_{\mathrm{B}}\right), 3.23\left(3 \mathrm{H}, \mathrm{s}, \mathrm{OSO}_{2} \mathrm{CH}_{3}\right), 3.58\left(1 \mathrm{H}, \mathrm{d}, J 11.1, \mathrm{C}(4) \mathrm{H}_{\mathrm{A}} \underline{\mathrm{H}}_{\mathrm{B}}\right), 3.76(3 \mathrm{H}$, s, $\left.\mathrm{CO}_{2} \mathrm{CH}_{3}\right), 4.70(1 \mathrm{H}, \mathrm{s}, J$ 9.7, $\mathrm{C}(2) \mathrm{H}) ; \delta_{\mathrm{C}}\left(100 \mathrm{MHz}, \mathrm{CDCl}_{3}\right): 8.6\left(\mathrm{C}^{(7)} \underline{\mathrm{CH}}_{3}\right), 19.6,20.2$ $\left.\left(\mathrm{CH}(\underline{\mathrm{CH}})_{3}\right)_{2}\right), 35.2(\mathrm{C}(4)), 36.9\left(\underline{\mathrm{CH}}\left(\mathrm{CH}_{3}\right)_{2}\right), 39.5\left(\mathrm{OSO}_{2} \mathrm{CH}_{3}\right), 53.7\left(\mathrm{CO}_{2} \underline{\mathrm{CH}_{3}}\right), 66.8(\mathrm{C}(2)), 78.2$ (C(5)), $124.0(\mathrm{C}(7)), 154.0\left(\underline{\mathrm{CO}}_{2} \mathrm{CH}_{3}\right), 168.4(\mathrm{C}(8)), 171.4(\mathrm{C}(6)) ; \mathrm{m} / \mathrm{z}\left([\mathrm{ESI}]^{+}\right) 372.0\left([\mathrm{M}+\mathrm{Na}]^{+}\right.$, $100 \%)$; HRMS $\left([\mathrm{ESI}]^{+}\right)$found $372.0547, \mathrm{C}_{13} \mathrm{H}_{19} \mathrm{NNaO}_{6} \mathrm{~S}_{2}\left([\mathrm{M}+\mathrm{Na}]^{+}\right)$requires 372.0546. 
Suzuki Coupling: ${ }^{17}$ A mixture of 1,4-bis(diphenylphosphino)butane $(0.06$ eq) and bis(benzonitrile)palladium(II) chloride (0.05 eq) in dry toluene was stirred at room temperature under nitrogen atmosphere for 30 minutes to form a creamy orange slurry of [1,4bis(diphenylphosphino)butane] palladium(II) chloride. Mesylate (1.0 eq), boronic acid (1.05-1.8 eq), ethanol (7.0 eq), 1M aqueous sodium carbonate solution (9-18 eq) and dry toluene were added to the catalyst and the mixture was refluxed for 3-30 hours. After cooling, water was added, and the mixture was diluted with ethyl acetate. The aqueous phase was separated and extracted with ethyl acetate. The combined organic phases were dried and evaporated in vacuo to find the crude product, which was then purified by flash column chromatography.

Representative reaction: Mesylate 7a $(210 \mathrm{mg}, \quad 0.66 \quad \mathrm{mmol})$ was reacted with 4methoxyphenylboronic acid (150 mg, $0.98 \mathrm{mmol}), \mathrm{PdCl}_{2}(\mathrm{dppb}), 1 \mathrm{M}$ aqueous $\mathrm{Na}_{2} \mathrm{CO}_{3}$ solution $(0.62 \mathrm{~mL}, 5.94 \mathrm{mmol})$ in ethanol $(0.27 \mathrm{~mL}, 4.62 \mathrm{mmol})$ and toluene $(12 \mathrm{~mL})$ for $6 \mathrm{~h} . \mathrm{PdCl}_{2}(\mathrm{dppb})$ was prepared from $\left(\mathrm{C}_{6} \mathrm{H}_{5}\right)_{2} \mathrm{P}\left(\mathrm{CH}_{2}\right)_{4} \mathrm{P}\left(\mathrm{C}_{6} \mathrm{H}_{5}\right)_{2}(16.9 \mathrm{mg}, 0.04 \mathrm{mmol})$ and $\left(\mathrm{C}_{6} \mathrm{H}_{5} \mathrm{CN}\right)_{2} \mathrm{PdCl}_{2}(12.6 \mathrm{mg}$, $0.022 \mathrm{mmol})$ in toluene $(2 \mathrm{~mL})$. Yield 47\% (102 mg); yellow solid, m. p. 90-92 ${ }^{\circ} \mathrm{C} ; \mathrm{R}_{\mathrm{f}}(30 \%$ EtOAc in Petrol) 0.25; $[\alpha]_{a}^{25}+138.9\left(c 1.0\right.$ in DCM); $v_{\max } / \mathrm{cm}^{-1} 2954(\mathrm{C}-\mathrm{H}), 2868(\mathrm{C}-\mathrm{H}), 1743(\mathrm{C}=\mathrm{O}), 1712$ $(\mathrm{C}=\mathrm{O}) ; \delta_{\mathrm{H}}\left(400 \mathrm{MHz}, \mathrm{CDCl}_{3}\right): 0.91\left(6 \mathrm{H}, \mathrm{dd}, J\right.$ 8.9, 6.8, $\left.\mathrm{HC}\left(\mathrm{C}_{3}\right)_{2}\right), 1.80(1 \mathrm{H}, \mathrm{dq}, J$ 6.8, 5.6, $\left(\underline{\mathrm{HC}}\left(\mathrm{CH}_{3}\right)_{2}\right), 3.48\left(1 \mathrm{H}, \mathrm{d}, J\right.$ 8.3, $\left.\mathrm{C}(4) \underline{\mathrm{H}_{A}} \mathrm{H}_{\mathrm{B}}\right), 3.59\left(3 \mathrm{H}, \mathrm{s}, \mathrm{CO}_{2} \mathrm{CH}_{3}\right), 3.77\left(3 \mathrm{H}, \mathrm{s}, \mathrm{OCH}_{3}\right), 4.84(1 \mathrm{H}, \mathrm{d}$, $J$ 5.6, C(2)H), $5.02\left(1 \mathrm{H}, \mathrm{d}, J\right.$ 8.3, C(4) $\left.\mathrm{H}_{\mathrm{A}} \underline{\mathrm{H}}_{\mathrm{B}}\right), 6.19(1 \mathrm{H}, \mathrm{s}, \mathrm{C}(7) \mathrm{H}), 6.86\left(2 \mathrm{H}, \mathrm{d}, J\right.$ 8.9, $\left.\mathrm{C}\left(3^{\prime}\right) \mathrm{H}\right), 7.31$ $\left(2 \mathrm{H}, \mathrm{d}, J\right.$ 8.9, $\left.\mathrm{C}\left(2^{\prime}\right) \mathrm{H}\right) ; \delta_{\mathrm{C}}\left(100 \mathrm{MHz}, \mathrm{CDCl}_{3}\right): 17.1,17.1\left(\mathrm{HC}\left(\underline{\mathrm{C}} \mathrm{H}_{3}\right)_{2}\right), 33.2\left(\mathrm{H}_{\underline{C}}\left(\mathrm{CH}_{3}\right)_{2}\right), 53.3$ $\left(\mathrm{CO}_{2} \underline{\mathrm{CH}}_{3}\right), 55.5\left(\mathrm{OCH}_{3}\right), 70.3(\mathrm{C}(4)), 76.8(\mathrm{C}(5)), 93.5(\mathrm{C}(2)), 114.7\left(\mathrm{C}\left(3^{\prime}\right)\right), 119.0(\mathrm{C}(7)), 122.5$ (C(1')), $128.8\left(\mathrm{C}\left(2^{\prime}\right)\right), 159.3(\mathrm{C}(6)), 161.9\left(\mathrm{C}\left(4^{\prime}\right)\right), 170.1\left(\underline{\mathrm{CO}}_{2} \mathrm{CH}_{3}\right), 177.5(\mathrm{C}(8)) ; \mathrm{m} / \mathrm{z}\left([\mathrm{ESI}]^{+}\right)$ $332.1\left([\mathrm{M}+\mathrm{H}]^{+}, 30 \%\right)$; HRMS $\left([\mathrm{ESI}]^{+}\right)$found 332.1493, $\mathrm{C}_{18} \mathrm{H}_{22} \mathrm{NO}_{5}\left([\mathrm{M}+\mathrm{H}]^{+}\right)$requires 332.1493.

Low temperature single crystal X-ray diffraction data were collected using a (Rigaku) Oxford Diffraction SuperNova diffractometer. Raw frame data were reduced using CrysAlisPro and the structures were solved using 'Superflip'. ${ }^{18}$ before refinement with CRYSTALS ${ }^{19}$ as per 
the SI (CIF). Crystallographic data have been deposited with the Cambridge Crystallographic Data Centre as supplementary publication no. CCDC 1961419-21 and can be obtained via www. ccdc.cam.ac.uk/data_request/cif.

1. Bagum, H.; Christensen, K. E.; Genov, M.; Pretsch, A.; Pretsch, D.; Moloney, M. G. J. Org. Chem. 2019, 84, 10257-10279.

2. Bagum, H.; Christensen, K. E.; Pretsch, A.; Genov, M.; Pretsch, D.; Moloney, M. G. Tetrahedron 2019, 75, 130561-130583; Josa-Cullere, L.; Moloney, M. G.; Thompson, A. L. Synlett 2016, 27, (11), 1677-1681.

3. Andrews, M. D.; Brewster, A. G.; Crapnell, K. M.; Ibbett, A. J.; Jones, T.; Moloney, M. G.; Prout, K.; Watkin, D. J. Chem. Soc., Perkin Trans. 1 1998, (2), 223-235.

4. Panduwawala, T. D.; Iqbal, S.; Tirfoin, R.; Moloney, M. G. Org. Biomol. Chem. 2016, 14, 4464-4478; Panduwawala, T. D.; Josa-Cullere, L.; Kuprov, I.; Odell, B.; Moloney, M. G.; Claridge, T. D. W. J. Org. Chem 2016, 81, (10), 4142-4148.

5. $\quad$ Lazar, L.; Fulop, F. Eur. J. Org. Chem. 2003, (16), 3025-3042.

6. Lazar, L.; Goblyos, A.; Martinek, T. A.; Fulop, F. J. Org. Chem 2002, 67, (14), 4734-4741; Fulop, F.; Mattinen, J.; Pihlaja, K. Tetrahedron 1990, 46, 6545-6552; Fulop, F.; Pihlaja, K.; Mattinen, J.; Bernath, G. J. Org. Chem. 1987, 52, 3821-3825.

7. $\quad$ Seebach, D.; Aebi, J. D. Tetrahedron Lett. 1984, 25, 2545-2548.

8. Jeong, Y.-C.; Anwar, M.; Nguyen, T. M.; Tan, B. S. W.; Chai, C. L. L.; Moloney, M. G. Org. Biomol. Chem. 2011, 9, 6663-6669.

9. Fulop, F.; Pihlaja, K.; Neuvonen, K.; Bernath, G.; Argay, G.; Kalman, A. J. Org. Chem. 1993, 58, 1967-1969.

10. Dieckmann Cyclisation: ${ }^{3}$ To a solution of $N$-acyl oxazolidine or thiazolidine $\mathbf{5 a , b}(1.0$ eq) in anhydrous THF was added potassium tert-butoxide (1.05 eq). The mixture was heated at reflux for $3 \mathrm{~h}$. The reaction mixture was separated between $\mathrm{Et}_{2} \mathrm{O}$ and water, the aqueous phase was acidified with $2 \mathrm{M}$ aqueous $\mathrm{HCl}$ and extracted with EtOAc. The organic layer was washed with a $1 \mathrm{M}$ aqueous solution of $\mathrm{NaH}_{2} \mathrm{PO}_{4}$ and brine, dried over anhydrous $\mathrm{Na}_{2} \mathrm{SO}_{4}$ and concentrated under reduced pressure to give the methyl ester tetramic acids 6a-e.

Synthesis of Mesylate: ${ }^{\mathbf{1 6}}$ Tetramic acid 6a-e (1.0 eq) was dissolved in DCM under nitrogen atmosphere. Methanesulfonyl chloride (1 eq) and DIPEA (2 eq) were added to this solution. The resulting mixture was stirred for 2-6 h at room temperature until total consumption of the starting material. The reaction mixture was washed with $5 \% \mathrm{HCl}, 5 \% \mathrm{NaHCO}_{3}$, and brine, dried over $\mathrm{MgSO}_{4}$, and filtered. The solvent was removed in vacuo, and the residue was chromatographed on silica gel using ethyl acetate:petroleum ether as eluants to give mesylates 7a,c.

Representative reaction: Tetramic acids $(\mathbf{6 d}+\mathbf{6 e}, 2.32 \mathrm{~g}, 8.55 \mathrm{mmol})$ was reacted with $\mathrm{MsCl}$ (0.66 mL, $8.55 \mathrm{mmol})$ and DIPEA (2.9 mL, $17.1 \mathrm{mmol})$ in DCM (85 mL). Purification by flash column chromatography (20-30\% EtOAc in petroleum ether) furnished isolated mesylates 7d and 7e. Yield 61\% (1.82 g); colourless oil; $\mathrm{R}_{\mathrm{f}}\left(40 \%\right.$ EtOAc in Petrol) 0.37; $[\alpha]_{\mathrm{a}}^{2.5}+235.0$ (c 1.0 in DCM); $v_{\max } / \mathrm{cm}^{-1} 2960(\mathrm{C}-\mathrm{H}), 2935(\mathrm{C}-\mathrm{H}), 1747(\mathrm{C}=0), 1713(\mathrm{C}=0)$; $\delta_{\mathrm{H}}\left(400 \mathrm{MHz}, \mathrm{CDCl}_{3}\right)$ : 0.87 (3H, d, J 6.6, $\left.\mathrm{CH}\left(\mathrm{C}_{3}\right)\right), 1.02\left(3 \mathrm{H}, \mathrm{d}, J 6.6, \mathrm{CH}\left(\underline{\mathrm{H}}_{3}\right)\right), 1.78-1.84\left(1 \mathrm{H}, \mathrm{m}, \mathrm{C} \underline{\mathrm{H}}\left(\mathrm{CH}_{3}\right)_{2}\right), 1.85$ (3H, s, C(7) $\left.\mathrm{CH}_{3}\right), 2.84\left(1 \mathrm{H}, \mathrm{d}, J 11.1, \mathrm{C}(4) \underline{\mathrm{H}}_{\mathrm{A}} \mathrm{H}_{\mathrm{B}}\right), 3.23\left(3 \mathrm{H}, \mathrm{s}, \mathrm{OSO}_{2} \mathrm{CH}_{3}\right), 3.58(1 \mathrm{H}, \mathrm{d}, J 11.1$, $\left.\mathrm{C}(4) \mathrm{H}_{\mathrm{A}} \underline{\mathrm{H}_{\mathrm{B}}}\right), 3.76\left(3 \mathrm{H}, \mathrm{s}, \mathrm{CO}_{2} \mathrm{CH}_{3}\right), 4.70\left(1 \mathrm{H}, \mathrm{s}, J\right.$ 9.7, C(2)H); $\delta_{\mathrm{C}}\left(100 \mathrm{MHz}, \mathrm{CDCl}_{3}\right): 8.6\left(\mathrm{C}(7) \underline{\mathrm{CH}}_{3}\right)$, 19.6, $20.2\left(\mathrm{CH}\left(\underline{\mathrm{CH}_{3}}\right)_{2}\right), 35.2(\mathrm{C}(4)), 36.9\left(\underline{\mathrm{CH}}\left(\mathrm{CH}_{3}\right)_{2}\right), 39.5\left(\mathrm{OSO}_{2} \mathrm{CH}_{3}\right), 53.7\left(\mathrm{CO}_{2} \underline{\mathrm{CH}}_{3}\right), 66.8$ 
(C(2)), 78.2 (C(5)), 124.0 (C(7)), $154.0\left(\mathrm{CO}_{2} \mathrm{CH}_{3}\right), 168.4(\mathrm{C}(8)), 171.4(\mathrm{C}(6)) ; \mathrm{m} / \mathrm{z}\left([\mathrm{ESI}]^{+}\right)$ $372.0\left([\mathrm{M}+\mathrm{Na}]^{+}, 100 \%\right)$; HRMS $\left([\mathrm{ESI}]^{+}\right)$found 372.0547, $\mathrm{C}_{13} \mathrm{H}_{19} \mathrm{NNaO}_{6} \mathrm{~S}_{2}\left([\mathrm{M}+\mathrm{Na}]^{+}\right)$requires 372.0546.

Suzuki Coupling:17 A mixture of 1,4-bis(diphenylphosphino)butane $(0.06$ eq) and bis(benzonitrile)palladium(II) chloride $(0.05 \mathrm{eq})$ in dry toluene was stirred at room temperature under nitrogen atmosphere for 30 minutes to form a creamy orange slurry of [1,4-bis(diphenylphosphino)butane] palladium(II) chloride. Mesylate (1.0 eq), boronic acid (1.05-1.8 eq), ethanol (7.0 eq), 1M aqueous sodium carbonate solution (9-18 eq) and dry toluene were added to the catalyst and the mixture was refluxed for 3-30 hours. After cooling, water was added, and the mixture was diluted with ethyl acetate. The aqueous phase was separated and extracted with ethyl acetate. The combined organic phases were dried and evaporated in vacuo to find the crude product, which was then purified by flash column chromatography.

Representative reaction: Mesylate 7a (210 mg, $0.66 \mathrm{mmol})$ was reacted with 4methoxyphenylboronic acid (150 mg, $0.98 \mathrm{mmol}$ ), $\mathrm{PdCl}_{2}(\mathrm{dppb}), 1 \mathrm{M}$ aqueous $\mathrm{Na}_{2} \mathrm{CO}_{3}$ solution $(0.62 \mathrm{~mL}, 5.94 \mathrm{mmol})$ in ethanol $(0.27 \mathrm{~mL}, 4.62 \mathrm{mmol})$ and toluene $(12 \mathrm{~mL})$ for $6 \mathrm{~h}$. $\mathrm{PdCl}_{2}(\mathrm{dppb})$ was prepared from $\left(\mathrm{C}_{6} \mathrm{H}_{5}\right)_{2} \mathrm{P}\left(\mathrm{CH}_{2}\right)_{4} \mathrm{P}\left(\mathrm{C}_{6} \mathrm{H}_{5}\right)_{2}(16.9 \mathrm{mg}, 0.04 \mathrm{mmol})$ and $\left(\mathrm{C}_{6} \mathrm{H}_{5} \mathrm{CN}\right)_{2} \mathrm{PdCl}_{2}(12.6 \mathrm{mg}, 0.022 \mathrm{mmol})$ in toluene $(2 \mathrm{~mL})$. Yield 47\% (102 mg); yellow solid, m. p. 90-92 ${ }^{\circ} \mathrm{C}$; $\mathrm{R}_{\mathrm{f}}(30 \% \text { EtOAc in Petrol) 0.25; [ } \alpha]_{\mathrm{o}}^{25}+138.9$ (c 1.0 in DCM); $v_{\max } / \mathrm{cm}^{-1} 2954$ (C$\mathrm{H}), 2868(\mathrm{C}-\mathrm{H}), 1743(\mathrm{C}=0), 1712(\mathrm{C}=0)$; $\delta_{\mathrm{H}}\left(400 \mathrm{MHz}, \mathrm{CDCl}_{3}\right): 0.91(6 \mathrm{H}, \mathrm{dd}, J$ 8.9, 6.8, $\left.\mathrm{HC}\left(\mathrm{CH}_{3}\right)_{2}\right), 1.80\left(1 \mathrm{H}, \mathrm{dq}, J\right.$ 6.8, 5.6, $\left(\underline{\mathrm{HC}}\left(\mathrm{CH}_{3}\right) 2\right), 3.48\left(1 \mathrm{H}, \mathrm{d}, J\right.$ 8.3, $\left.\mathrm{C}(4) \underline{\mathrm{H}}_{\mathrm{A}} \mathrm{H}_{\mathrm{B}}\right), 3.59(3 \mathrm{H}, \mathrm{s}$, $\left.\mathrm{CO}_{2} \mathrm{CH}_{3}\right), 3.77(3 \mathrm{H}, \mathrm{s}, \mathrm{OCH} 3), 4.84(1 \mathrm{H}, \mathrm{d}, J 5.6, \mathrm{C}(2) \mathrm{H}), 5.02\left(1 \mathrm{H}, \mathrm{d}, J 8.3, \mathrm{C}(4) \mathrm{H}_{\mathrm{A}} \mathrm{H}_{\mathrm{B}}\right), 6.19(1 \mathrm{H}, \mathrm{s}$, $\mathrm{C}(7) \mathrm{H}), 6.86\left(2 \mathrm{H}, \mathrm{d}, J\right.$ 8.9, C(3')H), $7.31\left(2 \mathrm{H}, \mathrm{d}, J\right.$ 8.9, C(2')H ); $\delta_{\mathrm{c}}\left(100 \mathrm{MHz}, \mathrm{CDCl}_{3}\right): 17.1,17.1$ $\left(\mathrm{HC}\left(\underline{\mathrm{C}} \mathrm{H}_{3}\right)_{2}\right), 33.2\left(\mathrm{H} \underline{\mathrm{C}}\left(\mathrm{CH}_{3}\right)_{2}\right), 53.3\left(\mathrm{CO}_{2} \underline{\left.\mathrm{CH}_{3}\right)}, 55.5\left(\mathrm{OCH}_{3}\right), 70.3(\mathrm{C}(4)), 76.8(\mathrm{C}(5)), 93.5(\mathrm{C}(2))\right.$, 114.7 (C(3')), 119.0 (C(7)), 122.5 (C(1')), 128.8 (C(2')), 159.3 (C(6)), 161.9 (C(4')), 170.1 $\left(\mathrm{CO}_{2} \mathrm{CH}_{3}\right), 177.5(\mathrm{C}(8)) ; \mathrm{m} / \mathrm{z}\left([\mathrm{ESI}]^{+}\right) 332.1\left([\mathrm{M}+\mathrm{H}]^{+}, 30 \%\right) ;$ HRMS ([ESI $\left.]^{+}\right)$found 332.1493, $\mathrm{C}_{18} \mathrm{H}_{22} \mathrm{NO}_{5}\left([\mathrm{M}+\mathrm{H}]^{+}\right)$requires 332.1493.

11. Seebach, D.; Sting, A. R.; Hoffmann, M. Angew. Chem., Int. Ed. Engl. 1996, 35, 2708-2748. 12. Low temperature single crystal X-ray diffraction data were collected using a (Rigaku) Oxford Diffraction SuperNova diffractometer. Raw frame data were reduced using CrysAlisPro and the structures were solved using 'Superflip'. ${ }^{18}$ before refinement with CRYSTALS ${ }^{19}$ as per the SI (CIF). Crystallographic data have been deposited with the Cambridge Crystallographic Data Centre as supplementary publication no. CCDC 1961419-21 and can be obtained via www. ccdc.cam.ac.uk/data_request/cif.

13. Corey, E. J.; Reichard, G. A. J. Am. Chem. Soc. 1992, 114, 10677-10678.

14. Jeong, Y.-C.; Moloney, M. G. Synlett. 2009, 2487-2491

15. Dyer, J.; Keeling, S.; King, A.; Moloney, M. G. J. Chem. Soc., Perkin Trans. 1 2000, 27932804; Bailey, J. H.; Cherry, D. T.; Crapnell, K. M.; Moloney, M. G.; Shim, S. B.; Bamford, M.; Lamont, R. B. Tetrahedron 1997, 53, 11731-11744.

16. Li, W.-R.; Lin, S. T.; Hsu, N.-M.; Chern, M.-S. J. Org. Chem. 2002, 67, 4702-4706.

17. Jones, K.; Keenan, M.; Hibbert, F. A. Synlett 1996, 509-510.

18. Palatinus, L.; Chapuis, G. J. Appl. Cryst. 2007, 40, 786-790.

19. Parois, P.; Cooper, R. I.; Thompson, A. L. Chem. Cent. J. 2015, 9, 1-14; Cooper, R. I.; Thompson, A. L.; Watkin, D. J. J. Appl. Cryst. 2010, 43, 1100-1107. 